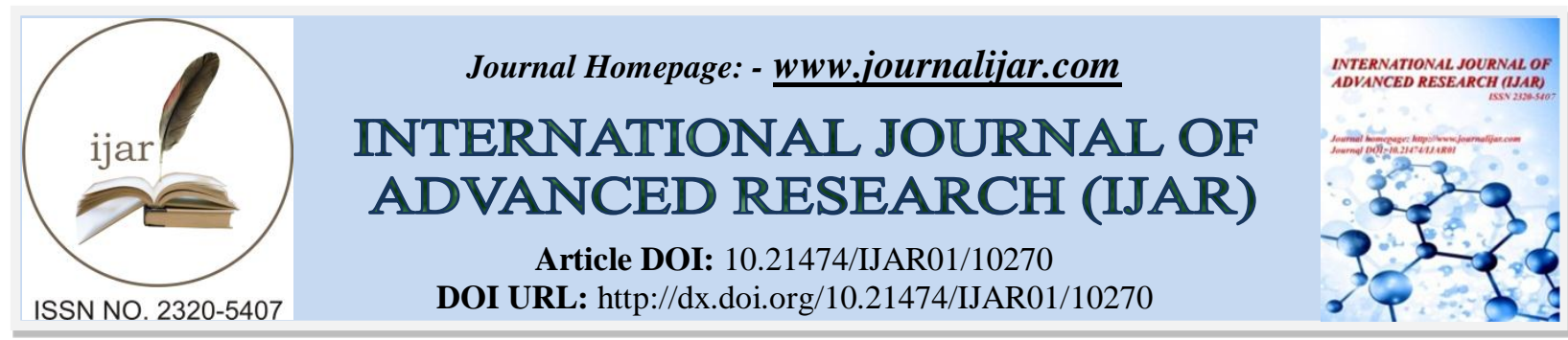

RESEARCH ARTICLE

\title{
PREVALANCE OF BREAST TUMORS IN FEMALES IN REPRODUCTIVE AGE IN KINGDOM OF SAUDI ARABIA
}

\section{Dr. Masoud Ahmad Al-Ghamdi ${ }^{1}$, Dr. Hoda Jehad Abousada ${ }^{2}$, Raghad Saad Alshahrani ${ }^{2}$, Raffal} Abdulmenaam Alshaikhh ${ }^{2}$, Shahad Awad Alqahtani ${ }^{2}$ and Ensaf Adnan Albokhari ${ }^{2}$

1. Consultanat General, Laproscopic And Colorectal Surgery At The Surgery Department in King Fahad General Hospital, Jeddah.

2. MBBS, BSHC, KSA (Postal Address: Jeddah, Al-Thaghr Neighborhood., 22338.

\section{Manuscript Info}

Received: 20 November 2019

Final Accepted: 23 December 2019

Published: January 2020

\section{Introduction:-}

The breast tumor is a widespread problem, Women suffer greatly, and at this time men also suffer from it, For females, the likelihood of this problem may increase in the reproductive period Because of the relationship with hormones, especially if we talk about breast cancer, the cancer cells grow in response to the hormone estrogen.

Although many cases of breast tumors have been recorded, whether they are benign or malignant, but most of these cases have been discovered in the last stages or even stages associated with complications, This is due to several reasons, The most important and the worst of these reasons: feeling ashamed to go to a doctor and do medical examination This has nothing to do with scientific ignorance, Many learners even higher education, ashamed of medical examination, Science ignorance may have something to do with shame, but this is not remarkable.

\section{Other reasons:}

1. Lack of knowledge of the importance of detecting the disease in the early stages, Which facilitate the treatment plan.

2. Lack of awareness about breast self-examination.

And many other causes that increase the spread of the disease and increase the proportion of deaths due to breast cancer in particular.

In this research we will depend on the detection of the extent of the incidence of breast tumors, whether benign or malignant and at any stage has been discovered and the extent of awareness about this disease problem.

\section{Rationale :}

This research is important in considering the prevalence of breast tumors in females in particular in the reproductive period of age, at what stage was discovered and the reasons that led to the delay in detection or delay in the start of treatment.

Corresponding Author:- Dr. Hoda Jehad Abousada

Address:- MBBS, BSHC, KSA (postal address: jeddah, Al-Thaghr neighborhood., 22338. 
Whether for reasons of scientific ignorance or shyness or not to consider this problem seriously. Making it easier to solve the problem or minimize its risks after knowing the reasons leading to it.

\section{Literature review :}

According to the other previous study like:

Breast cancer correlates in a cohort of breast screening program participants in Riyadh, KSA. (Al-Amri FA, 2015), the result was: The mean age of cases was $48.5 \pm 7.1$ years. Age at marriage, number of pregnancy, age at menopause, oral contraceptive pills, breast feeding and family history of breast cancer in first-degree relative were identified as the most important correlates among the studied cohort, this study highlighted the risk factors of breast cancer which we will discuss in our research which means the importance of focusing on the risk factors of injury that may someday be caused to prevent the disease.

This study was a good study but the sample number should have been more significant than that to be considered sufficient.

Recent incidence and descriptive epidemiological survey of breast cancer in Saudi Arabia (S1 et al., 2015). The result was: The average age at the diagnosis of $\mathrm{BC}$ was 48 ; weighted average was 49.8 , and range 43-52. Which is considered close to the previous study (Al-Amri FA, 2015) so that two studies are different, but the results are close, which means the validity of the results. We will focus on the average age to add something related to risk factors and recent addition to what was concluded in 2015 like previous study.

\section{Research question:}

Questionnaire.

Aim:

To determine the prevalence of breast tumor in females in reproductive age.

The sub- objectives:

1. the extent of the effect of the discovery of the disease in the late stages and complications associated with it.

2. Determine the degree of awareness in this problem.

3. Relationship of positive family history and incidence of the disease.

4. Breast tumor relationship with the irregular menstrual cycle

5. Relationship of breast tumors using contraceptives.

6. Relationship of breast cancer with other cancers.

7. The relationship of breast tumors to immunological diseases.

\section{Method and Design:-}

Study design:

Cross sectional study.

\section{Study area:}

This study will be conducted in kingdom of saudia Arabia.

\section{Study setting:}

The study will be carried out by questionnaire.

\section{Study population:}

Adult famales in reproductive age IP and OP.

\section{Inclusion criteria :}

females

\section{Exclusion criteria :}

Males 


\section{Data Collection Methods:-}

Data collection tool:

Self-administered questionnaire partially constructed by the researcher with reference to already made questionnaire in another study .Validity will be checked by at consultant.

\section{Data collection technique:}

The researcher will distribute the questionnaire.

\section{Study Sample And Technique:}

\section{Sample size:}

More than 350

\section{Sample technique:}

Questionnaire.

\section{Data entry and statistical analysis:}

The data will be entered into a personal computer and it will be analyzed using Statistical Package for the Social Sciences (SPSS).

\section{Results:-}

The questioner for prevalence of breast tumors in females in reproductive age in kingdom of Saudi Arabia. 1501 responses were collected showing the following results and conclusion :

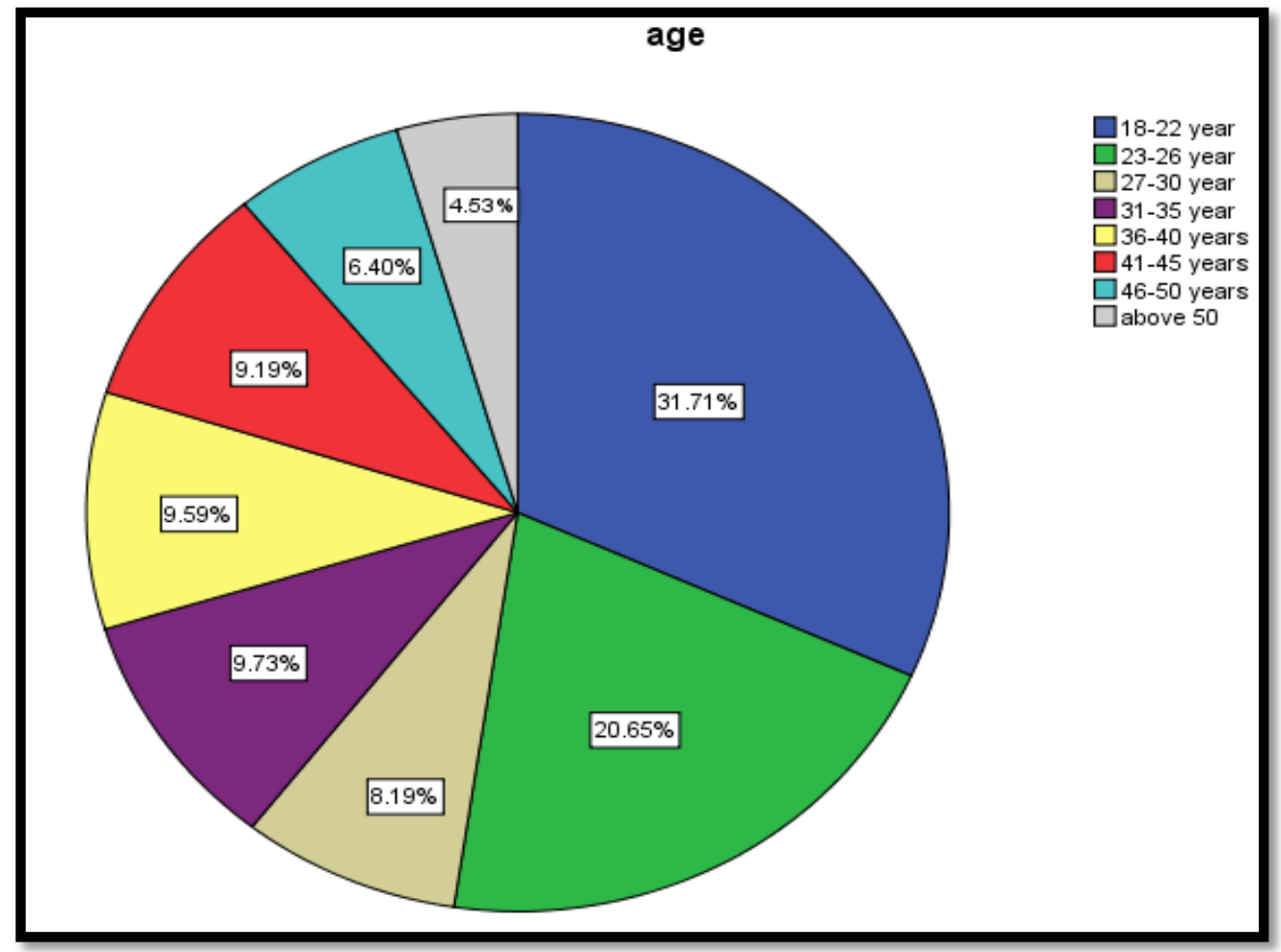

The results indicate that most respondents are between 31-35 years old. 


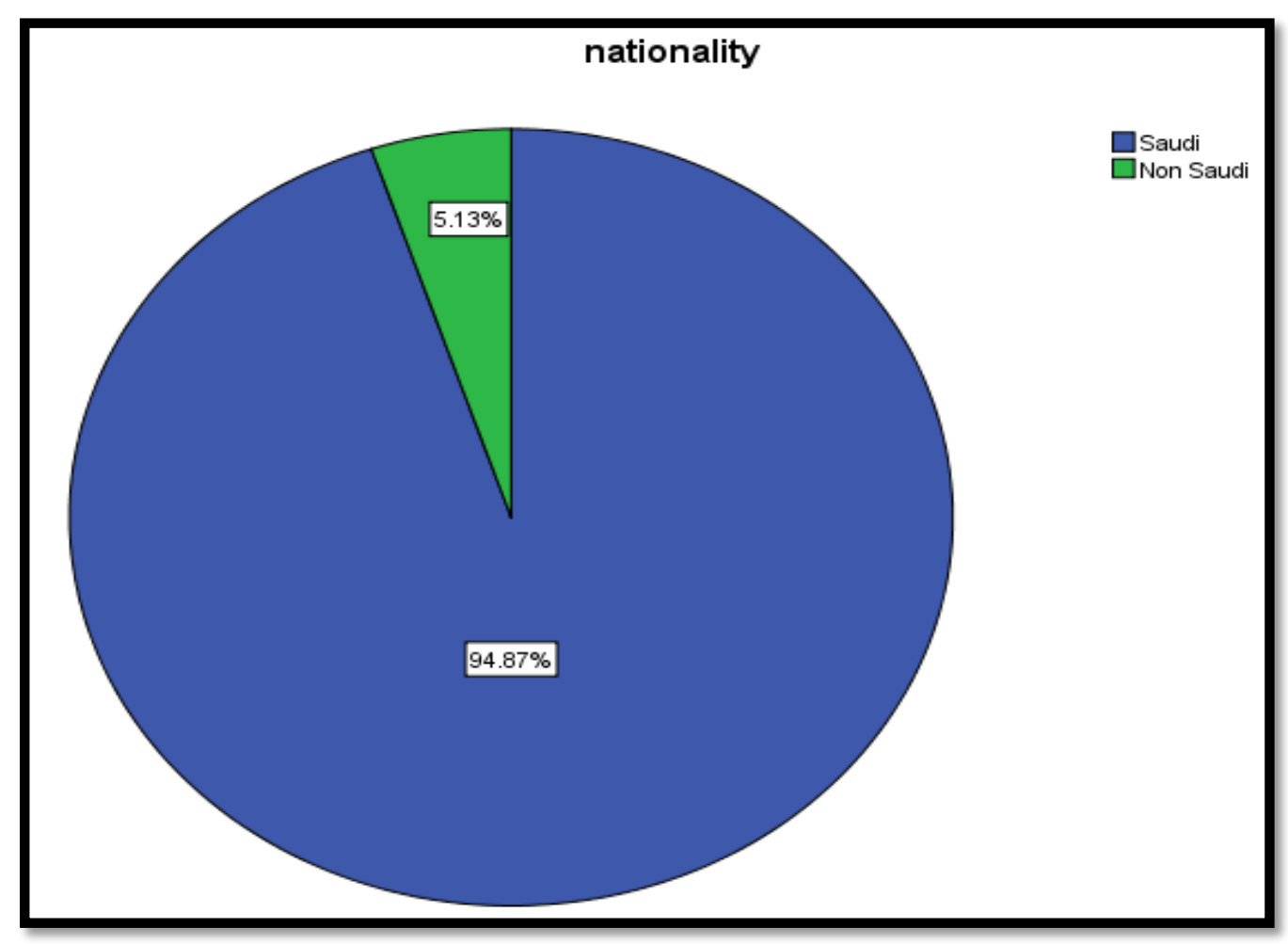

The results show that most of the respondents are Saudis.

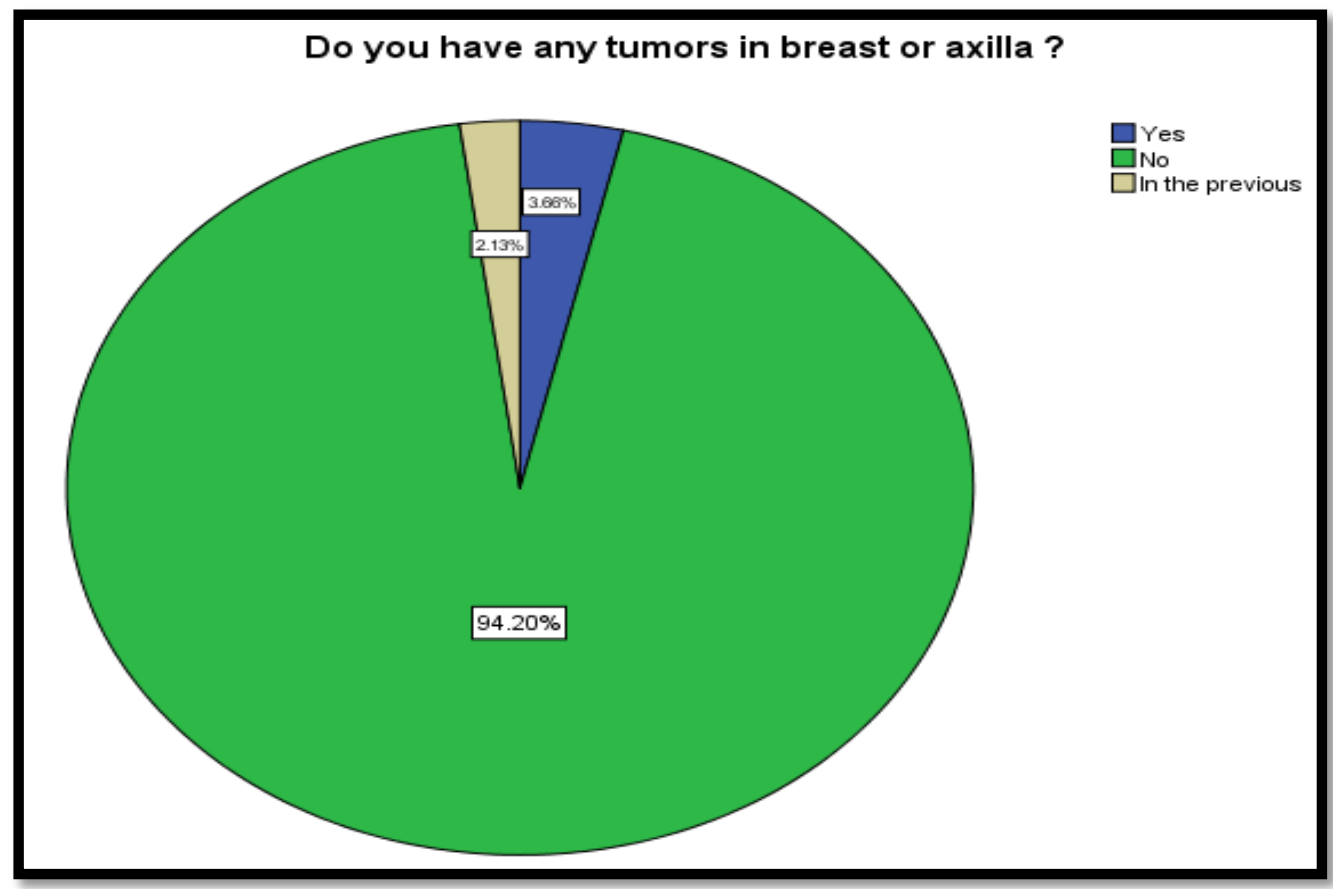

The results show that most of the respondents do not have any tumors in breast or axilla. 


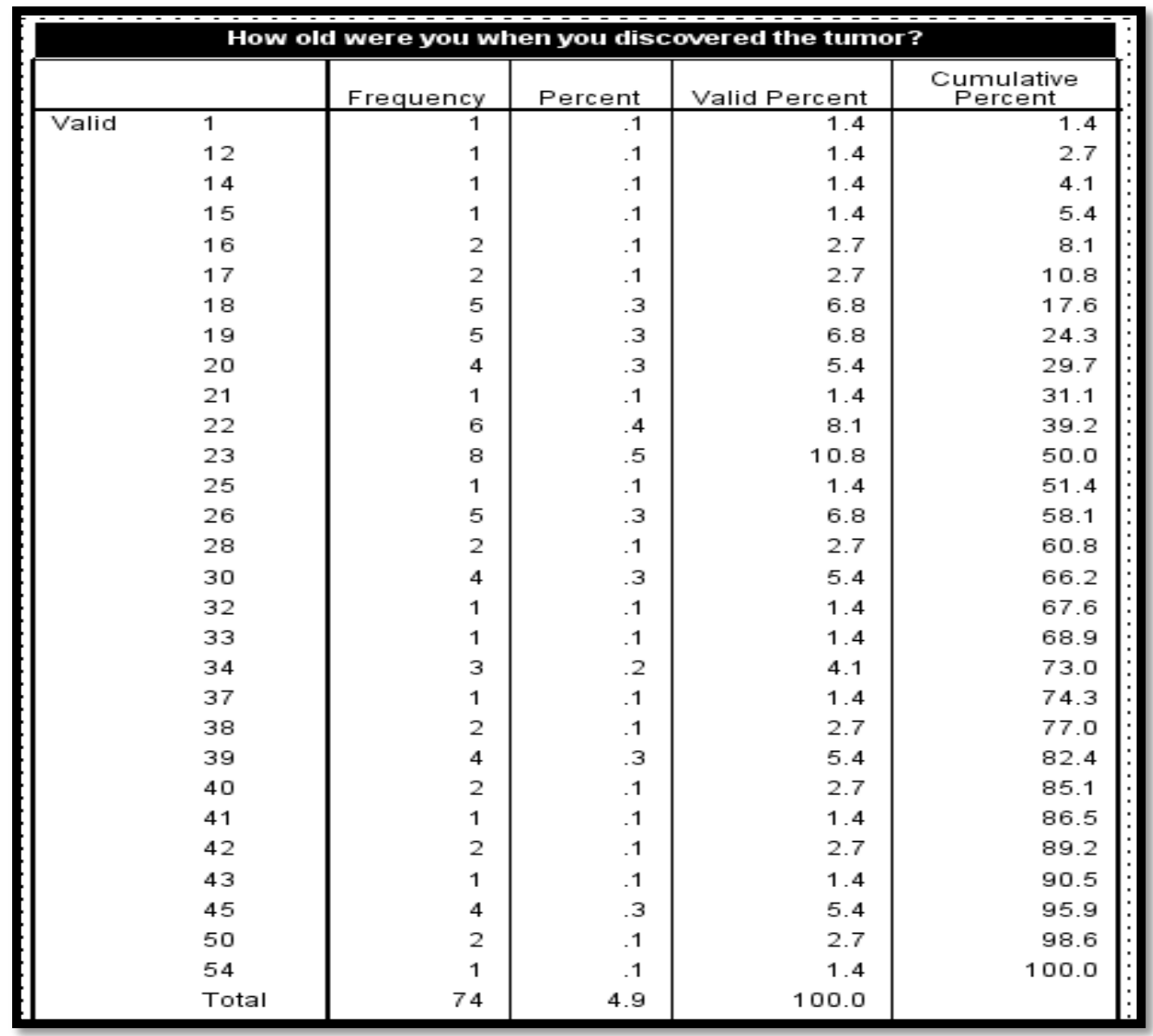

The answers of the respondents differed on the age at which they found the tumor, but most of them were over 18 years old

\begin{tabular}{|ll|r|r|r|r|}
\hline \multicolumn{5}{|c|}{ Place of tumor ? } \\
\hline & & Frequency & Percent & Valid Percent & $\begin{array}{c}\text { Cumulative } \\
\text { Percent }\end{array}$ \\
\hline Valid & Rt breast & 39 & 2.6 & 33.6 & 33.6 \\
& 39 & 2.6 & 33.6 & 67.2 \\
Lt breast & 12 & .8 & 10.3 & 77.6 \\
Rt and Lt breast & 8 & .5 & 6.9 & 84.5 \\
Rt axilla & 9 & .6 & 7.8 & 92.2 \\
Lt axilla & 5 & .3 & 4.3 & 96.6 \\
Rt axilla and Rt breast & 4 & .3 & 3.4 & 100.0 \\
Lt axilla and Lt breast & 116 & 7.7 & 100.0 & \\
Total & & & & \\
\hline
\end{tabular}

Most of the answers are left and right breast. 


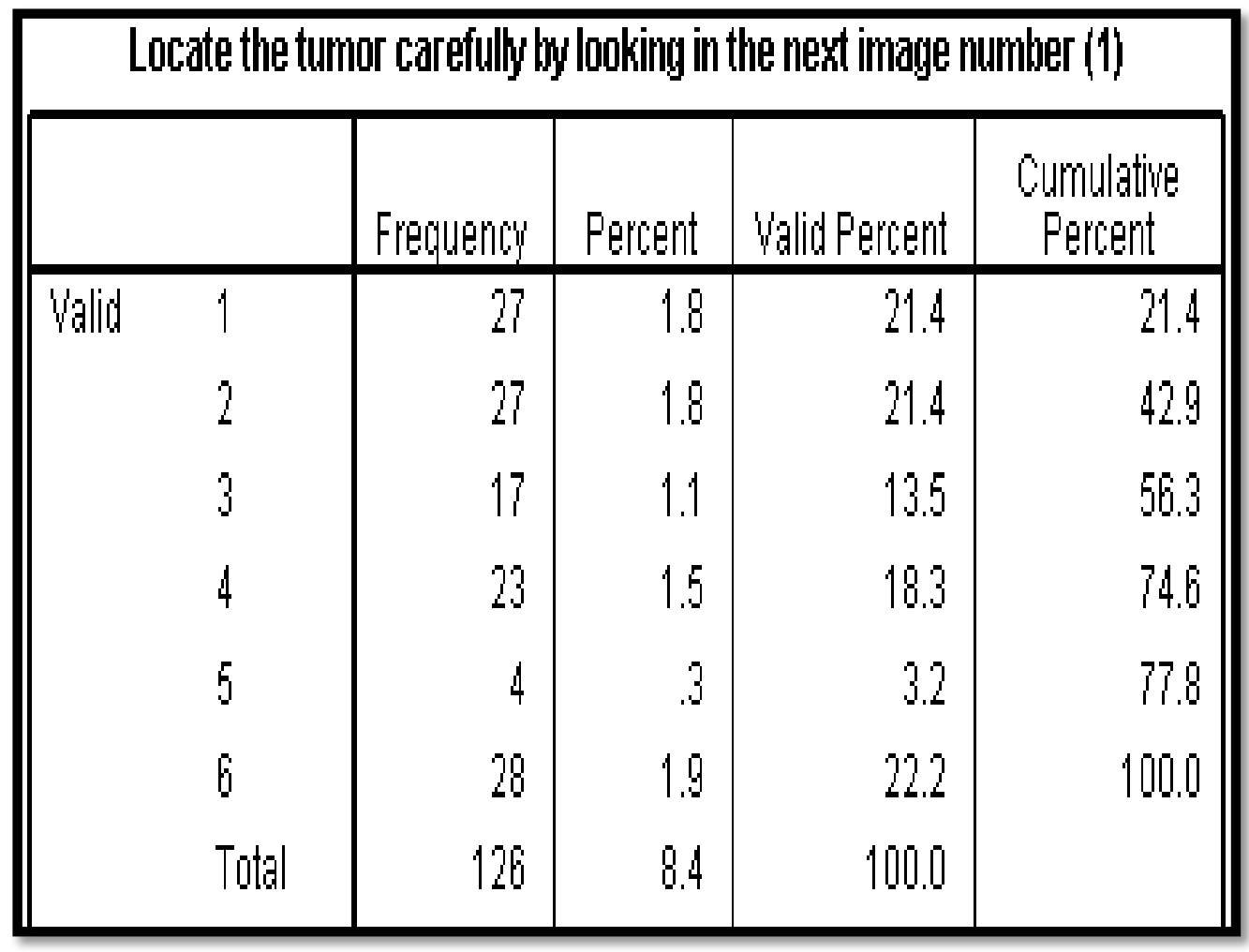

\begin{tabular}{|c|c|c|c|c|}
\hline \multicolumn{5}{|c|}{ Locate the tumor carefully by looking in the next image number (2) } \\
\hline & Freguentory & Percent & Wald Perent & $\begin{array}{c}\text { Culphlative } \\
\text { Perentt }\end{array}$ \\
\hline Walio & 14 & .9 & 120 & 120 \\
\hline 2 & 32 & 2.1 & 27.4 & 30.3 \\
\hline 3 & 15 & 1.0 & 128 & 52.1 \\
\hline 4 & 22 & 1.5 & 18.8 & 70.9 \\
\hline 5 & 11 & .7 & 9.4 & 80.3 \\
\hline 6 & 23 & 1.5 & 19.7 & 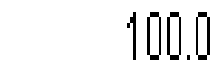 \\
\hline Total & 117 & 7.0 & 1][0] & \\
\hline
\end{tabular}

The results showed a diversity of answers about the location of the tumor. 


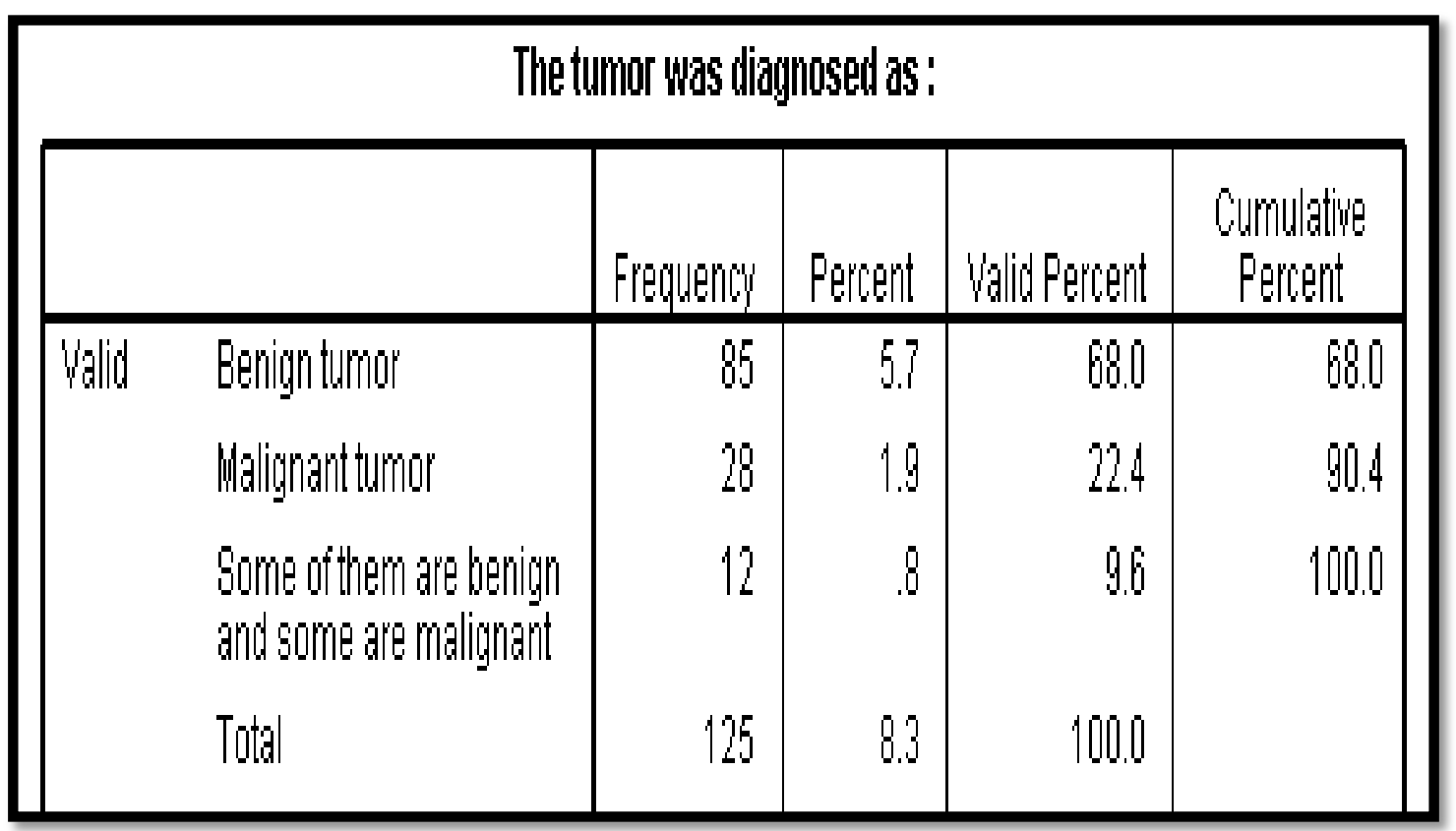

The results showed that most of the tumors were benign.

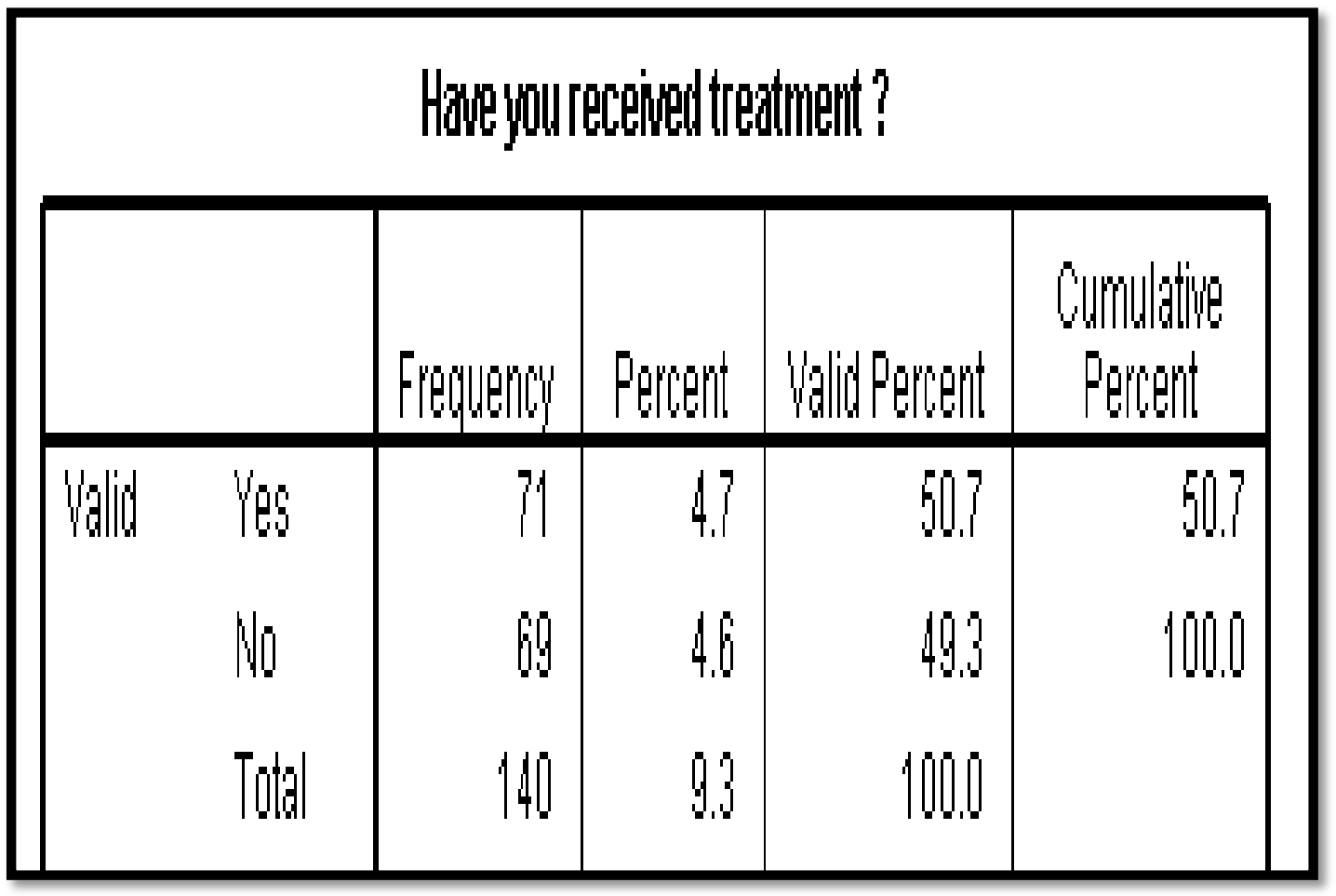

The proportions were the same among those who received treatment and those who did not receive treatment. 


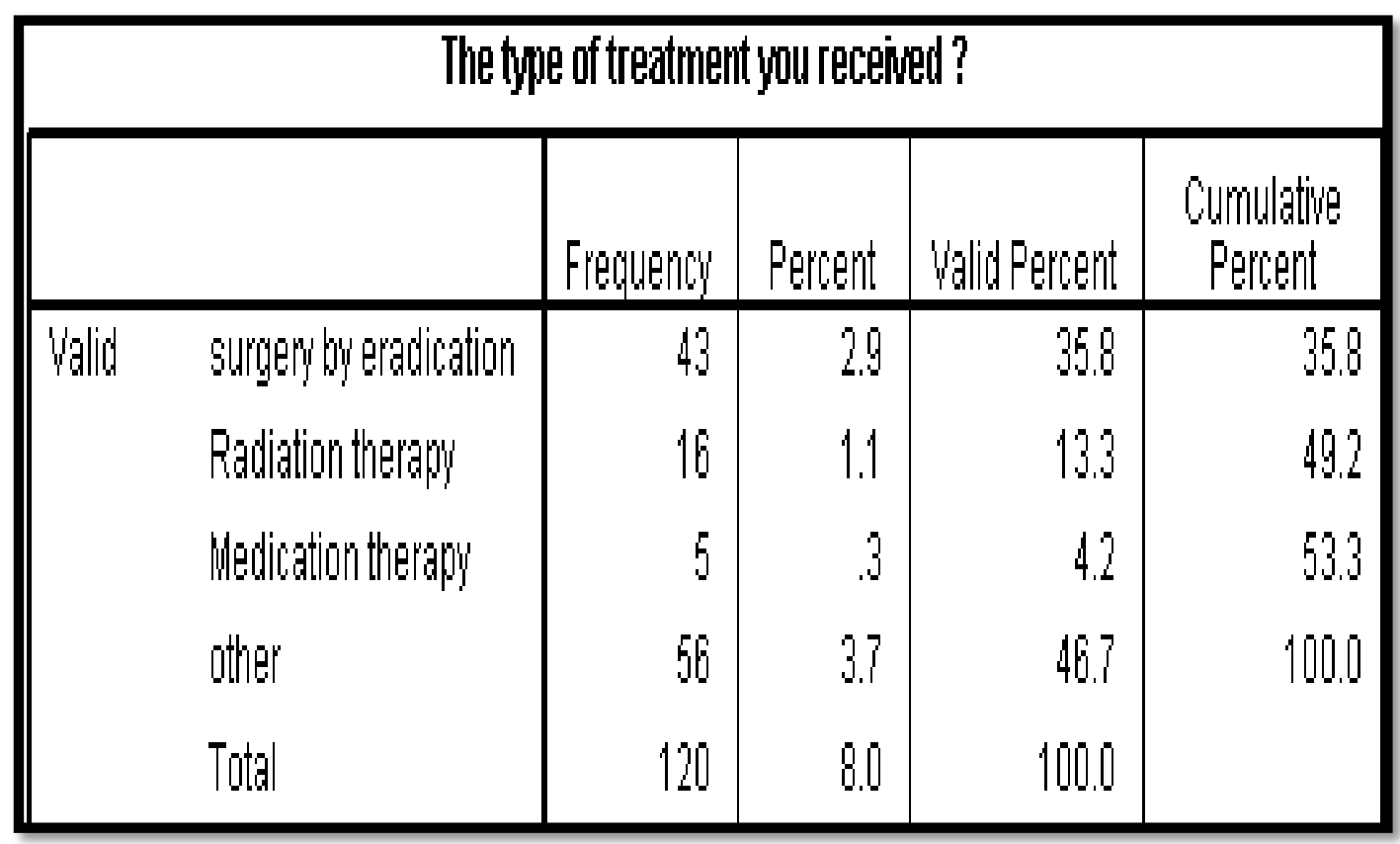

The results showed that the majority of respondents were treated with surgery by eradiction.

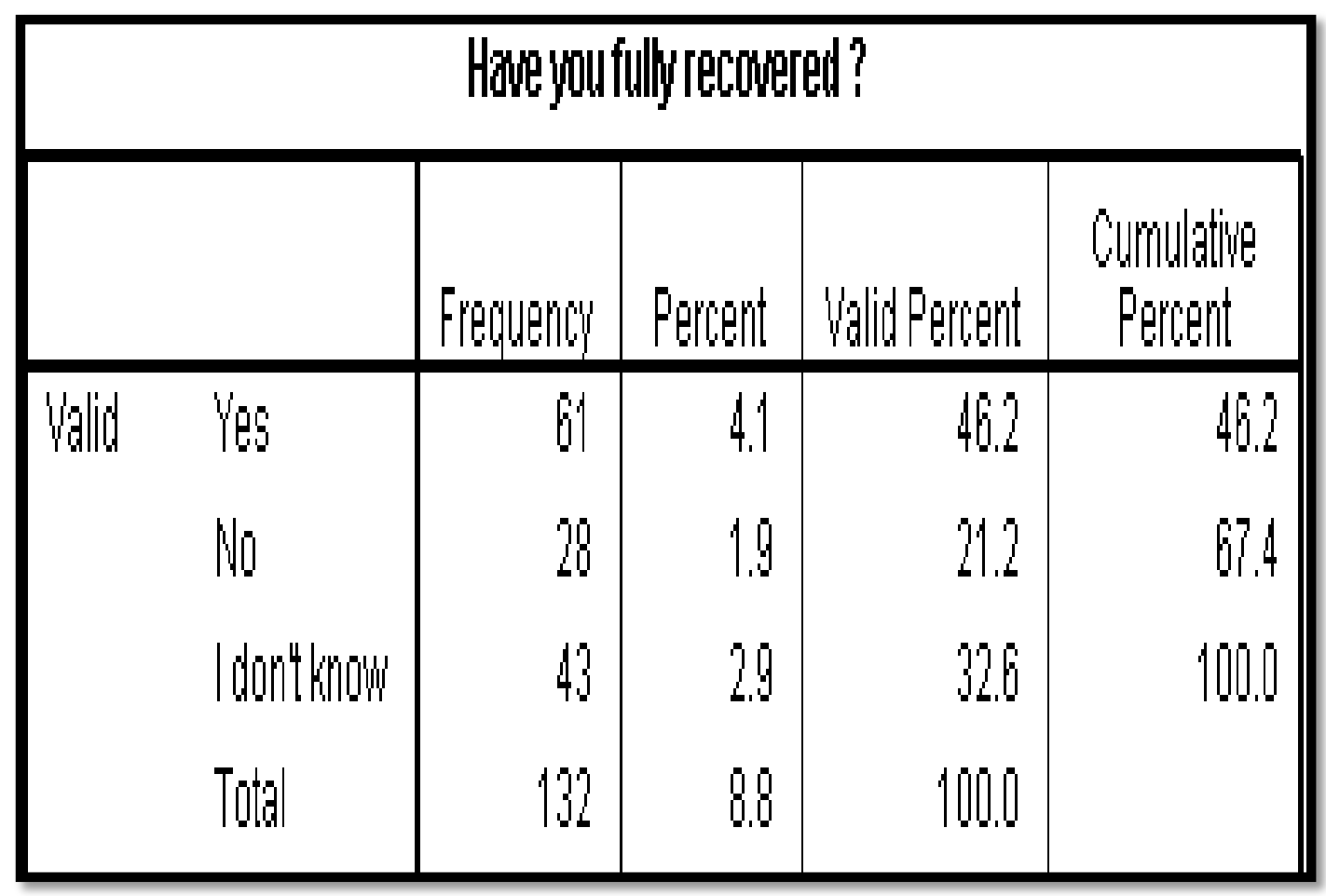

The results showed that the majority have recovered completely. 


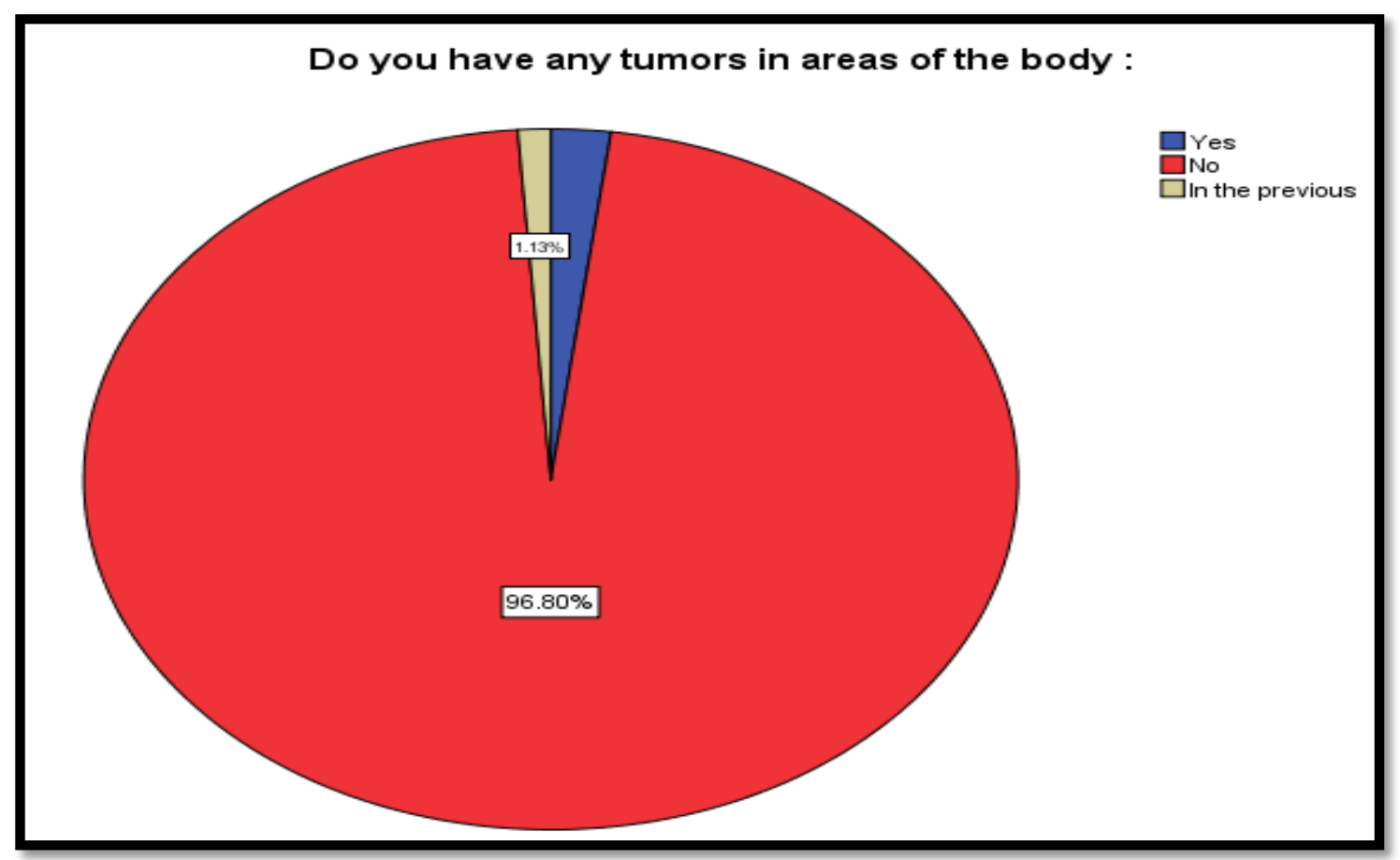

The results indicated that most respondents do not have tumors in areas of the body.

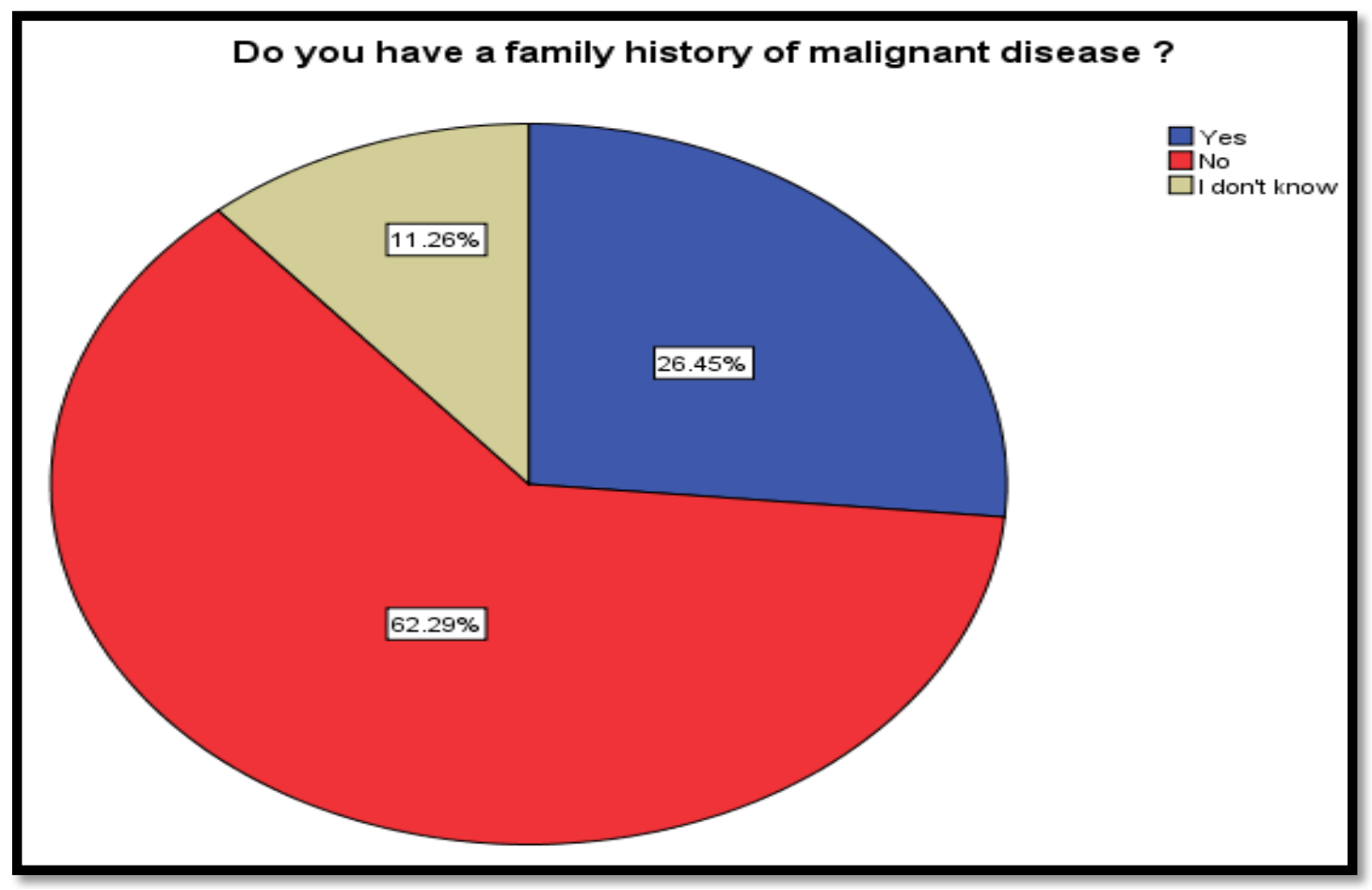

The results showed that a large percentage of the respondents do not have a family history of malignant diseases. 


\section{Correlations:}

\begin{tabular}{|c|c|c|c|}
\hline \multicolumn{4}{|c|}{ Correlations } \\
\hline & & $\begin{array}{c}\text { Do you have } \\
\text { any tumbrs in } \\
\text { breast or } \\
\text { axilla? }\end{array}$ & age \\
\hline \multirow{3}{*}{$\begin{array}{l}\text { Do you have any tumors } \\
\text { in breast or axilla? }\end{array}$} & Pearson Correlation & 1 & $-.0560^{*}$ \\
\hline & Sig. (2-tailed) & & .031 \\
\hline & N & 1501 & 1501 \\
\hline \multirow[t]{3}{*}{ age } & Pearson Correlation & $-.0560^{*}$ & 1 \\
\hline & Sig. (2-tailed) & .031 & \\
\hline & $N$ & 1501 & 1501 \\
\hline
\end{tabular}

$\mathrm{P}$ value is 0.031 which means there is a strong relationship between age and having tumors.

\begin{tabular}{|c|c|c|c|}
\hline \multicolumn{4}{|c|}{ Correlations } \\
\hline & & $\begin{array}{c}\text { The type of } \\
\text { treatronentyout } \\
\text { recentured? }\end{array}$ & $\begin{array}{c}\text { Have you filly } \\
\text { recoued? }\end{array}$ \\
\hline \multirow{3}{*}{$\begin{array}{l}\text { The type of treatrientyou } \\
\text { recentived ? }\end{array}$} & Pearson Correation & 1 & $.226^{\pi}$ \\
\hline & Gig. (2-tailed) & & . 016 \\
\hline & $\mathbb{N}$ & 120 & 114 \\
\hline \multirow{3}{*}{$\begin{array}{l}\text { Have you fully recolded } \\
?\end{array}$} & Pearson Correation & $.225^{x}$ & 1 \\
\hline & Sig. (2-taled) & .016 & \\
\hline & $\mathbb{N}$ & 114 & 132 \\
\hline
\end{tabular}

$\mathrm{P}$ value is 0.016 which means there is a strong relationship Between the type of treatment and the reality of complete treatment of the tumor. 


\begin{tabular}{|c|c|c|c|}
\hline \multicolumn{4}{|c|}{ Correlations } \\
\hline & & age & $\begin{array}{c}\text { The type of } \\
\text { treatrinent you } \\
\text { received? }\end{array}$ \\
\hline \multirow[t]{3}{*}{ age } & Pearson Correlation & 1 & $-.274^{7 x}$ \\
\hline & Sig. (2-tailed) & & 002 \\
\hline & $\mathbb{N}$ & 1501 & 120 \\
\hline \multirow{3}{*}{$\begin{array}{l}\text { The type of treatment you } \\
\text { pecelwed? }\end{array}$} & Pearson Correation & $-.274^{\mathrm{xn}}$ & 1 \\
\hline & Sig. (2-tailed) & .002 & \\
\hline & $N$ & 120 & 120 \\
\hline
\end{tabular}

$\mathrm{P}$ value is 0.002 which means there is a strong relationship Between the type of treatment and the age.

\begin{tabular}{|c|c|c|c|}
\hline \multicolumn{4}{|c|}{ Correlations } \\
\hline & & $\begin{array}{l}\text { Do you have a } \\
\text { family histony } \\
\text { of malighant } \\
\text { disease? }\end{array}$ & $\begin{array}{c}\text { Hawe you fully } \\
\text { reconered? }\end{array}$ \\
\hline \multirow{3}{*}{$\begin{array}{l}\text { Do you have a farrily } \\
\text { history of malignant } \\
\text { disease? }\end{array}$} & Pearson Corevation & 1 & $.175^{\pi}$ \\
\hline & Gig (2-tailed) & & .045 \\
\hline & $N$ & 1501 & 132 \\
\hline \multirow{3}{*}{$\begin{array}{l}\text { Have you fully recowered } \\
?\end{array}$} & Pearon Correlation & $.175^{2}$ & 1 \\
\hline & Gig (2-tailed) & .045 & \\
\hline & $N$ & 132 & 132 \\
\hline
\end{tabular}

$\mathrm{P}$ value is 0.045 which means there is a strong relationship Between being recovered and having a family history of malignant disease. 


\begin{tabular}{|c|c|c|c|}
\hline \multicolumn{4}{|c|}{ Correlations } \\
\hline & & $\begin{array}{l}\text { The tumor } \\
\text { was } \\
\text { diagnosed as }\end{array}$ & age \\
\hline \multirow{3}{*}{$\begin{array}{l}\text { The tumor was } \\
\text { diagnosed as: }\end{array}$} & Pearson Correlation & 1 & $.218^{x}$ \\
\hline & Sig. (2-tailed) & & .015 \\
\hline & $N$ & 125 & 125 \\
\hline \multirow[t]{3}{*}{ age } & Pearson Correlation & $.218^{x}$ & 1 \\
\hline & Sig. (2-tailed) & .015 & \\
\hline & $N$ & 125 & 1501 \\
\hline
\end{tabular}

$\mathrm{P}$ value is 0.015 which means there is a strong relationship Between age and the tumor diagnosis.

\begin{tabular}{|c|c|c|c|}
\hline \multicolumn{4}{|c|}{ Correlations } \\
\hline & & $\begin{array}{l}\text { Have you } \\
\text { received } \\
\text { treatment? }\end{array}$ & $\begin{array}{l}\text { The tumor } \\
\text { was } \\
\text { diagnosed as }\end{array}$ \\
\hline \multirow{3}{*}{$\begin{array}{l}\text { Have you received } \\
\text { treatment? }\end{array}$} & Pearson Correlation & 1 & $-263^{\mathrm{xx}}$ \\
\hline & Sig. (2-tailed) & & 005 \\
\hline & $\mathbb{N}$ & 140 & 114 \\
\hline \multirow{3}{*}{$\begin{array}{l}\text { The tumor was } \\
\text { diagnosed as: }\end{array}$} & Pearson Correlation & $-.263^{\mathrm{xx}}$ & 1 \\
\hline & Sig. (2-tailed) & .005 & \\
\hline & $N$ & 114 & 125 \\
\hline
\end{tabular}

$\mathrm{P}$ value is 0.005 which means there is a strong relationship Between receiving the treatment and the tumor diagnosis.

\section{Discussion:-}

This study was based on a number of 1501 participants, 55 of them had tumors in breast or axilla, and 32 of them had tumors in breast or axilla in the previous.

The current study showed statistically significant ( $\mathrm{P}$ value is 0.031 ) which means there is a strong relationship between age and having tumors. , (P value is 0.015) which means there is a strong relationship Between age and the tumor diagnosis. 
( $\mathrm{P}$ value is 0.005) which means there is a strong relationship Between receiving the treatment and the tumor diagnosis.

\section{Conclusion:-}

The results showed very positive results due to the low percentage of people with tumors. It is clear from the results that one of the factors that affects the type of tumor and its diagnosis is age. The results also showed that the largest percentage of the female respondents do not have a family history of tumors, and this is good thing .

In terms of treatment, a large proportion of the respondents were treated by the tumor eradication operations, not by medicines, and the largest proportion was treated.

\section{Recommendation:-}

we recommend setting up health education programs about the breast tumors, This health problem must be presented broadly and beneficially and, in a way, that everyone understands, as most deal with the breast tumors by ignoring and not being important, work should be done on health conferences and medical discussions on that.

\section{Acknowledgement:-}

The authors would like to thank the participants for their great cooperation, Participants will be carried out by questionnaire.

\section{We thank the data collectors:}

Reem Mohammed Alyousef, Fajr Abdulhadi Alnaami, Sara Abdullah Althumairy, Bushra Jameel Alturkistani

\section{Ethical considerations:}

Administrative approval will be sought from the unit of biomedical ethics research committee Ethical approval will be sought from the ethical committee of the faculty of medicine, king abdulaziz university. An informed consent will be sought from the participants.

\section{Source of funding:}

Self-Funded. This research did not receive any specific grant from funding agencies in the public, commercial, or not-for-profit sectors.

\section{Budget:}

Self funded.

\section{References:-}

1. 1. Al-Amri FA, e. (2015). Breast cancer correlates in a cohort of breast screening program participants in Riyadh, KSA. - PubMed - NCBI. [online] Ncbi.nlm.nih.gov. Available at: https://www.ncbi.nlm.nih.gov/pubmed/25935858 [Accessed 25 Apr. 2015].

2. S1, S., H, R., ZK, A. and AA, A. (2015). Recent incidence and descriptive epidemiological survey of breast cancer in Saudi Arabia.. [online] pubmed. Available at: https://www.ncbi.nlm.nih.gov/pubmed/26446327 [Accessed 10 Oct. 2015].

\section{Appendices:-}

( Questionnaire ):-

The questioner for prevalence of breast tumors in females in reproductive age in kingdom of Saudi Arabia. •استبيان لمدى انتشار أورام الثدي في الاناث في سن الانجاب في المملكة العربية السعودية.

\section{Age: العمر}

1. 18-22 years.

2. 23-26 years.

3. 27-30 years.

4. 31-35 years.

5. 36-40 years.

6. 41-45 years.

7. 46-50 years. 
8. Above 50 years

Nationality: الجنسية

1. Saudi سعودي

2. Non Saudi غير سعودي

هل لايك اي اورام في الثدي او الابط؟ ? Do you have any tumors in breast or axilla

1. Yes/ نع/

2. No/ע

3. In the previous / في السابق

كم كان عمرك عند اكتثاف الورم How old were you when you discovered the tumor?

Place of tumor?

1. Rt breast الثي الإيمن

2. Lt breast الثي الثايسن

3. Rt and Lt breast الثدي الايمن و الايسر

4. Rt axilla الابط الايمن الابطن

5. الابط الايسرن Lt axilla

6. Rt axilla and Rt breast الابطو الثدي الايمن

7. Lt axilla and Lt breast الابطو الثي الايسي

حدد مكان الورم بدقة عن طريق النظر الى الصورة القادمة (1) عocate the tumor carefully by looking in the next image number رقم 1

$\square \quad 1$
$\square \quad 2$
$\square \quad 3$
$\square \quad 4$
$\square \quad 5$
$\square \quad 6$

image number 1 Left breast صورة رقم 1 الثدي الايسر

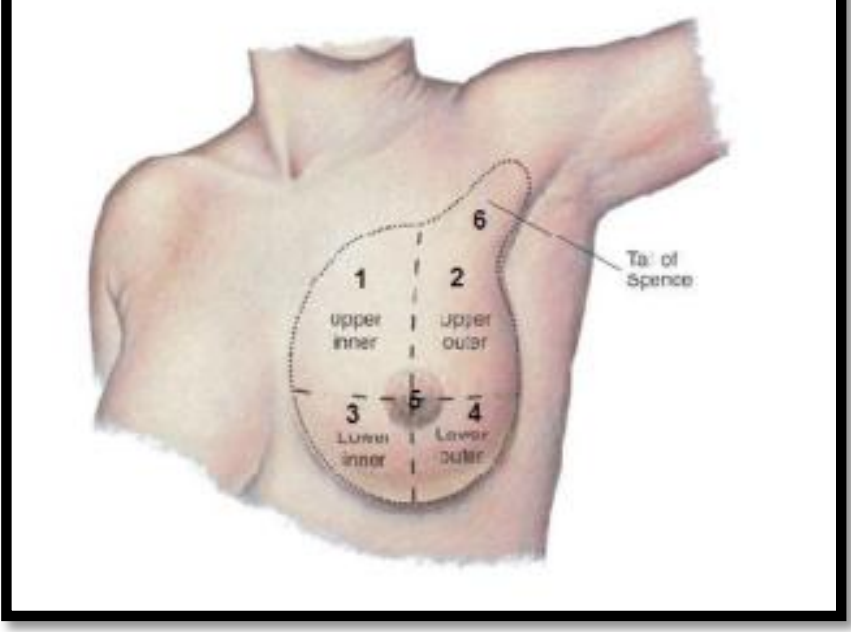

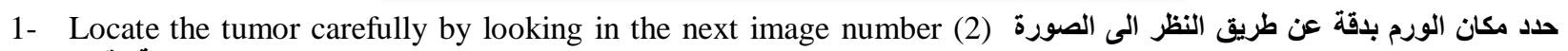
القادمة رقم 2 


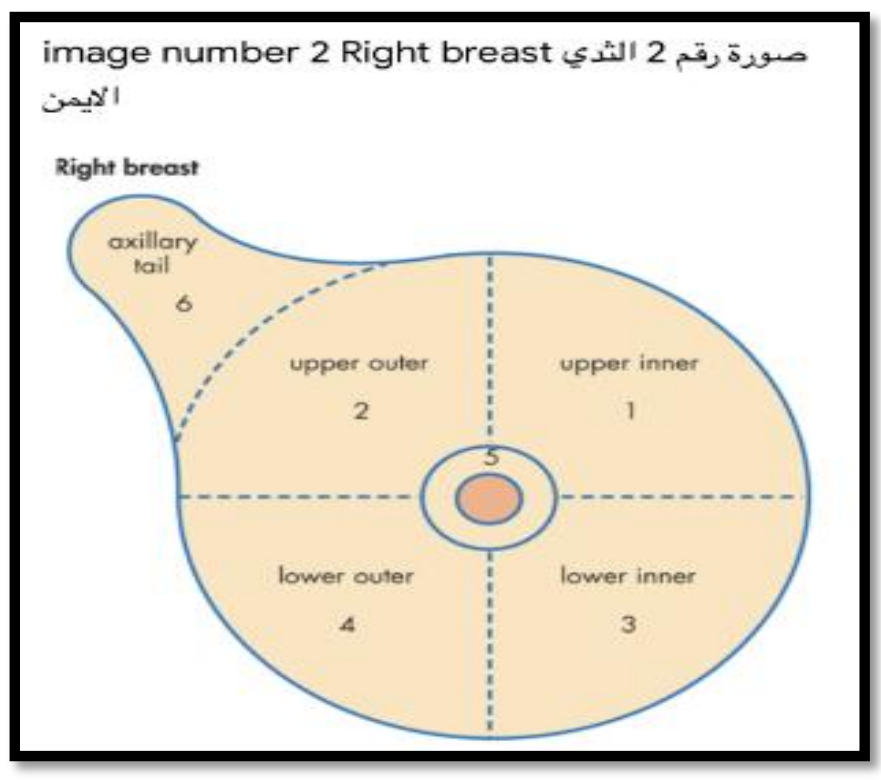

8- The tumor was diagnosed as :

1. Benign tumor ورم حميد

2. Malignant tumor ورم خبيث

3. Some of them are benign and some are malignant Sضض منها حميد وبعض منها خبيث

Have you received treatment ?ل تلقيت العلاج

1. Yes/ نع/

2. No/y

The type of treatment you received ? نوع العلاج الذي تلقيته

1. راحة عن طريق الاستئصال

2. Radiation therapy علاج اشعالعي

3. Medication therapy العلاج عن طريق الادوية

4.

Have you fully recovered ?ل شفيت تماما؟

1. Yes/ نع/

2. No/ע

هل لايكك اية اورام في مناطق من الجسم : Do you have any tumors in areas of the body

1. Yes/ نع/

2. No/y

3. In the previous / في السابق

هل لايك تاريخ عائلي مرضي للامراض الخبيثة ? Do you have a family history of malignant disease

1. Yes/ نع/

2. No/ע

3. I don't know / لا أعلم

\section{Thank you.}

